\title{
Pattern of Dermatological Cases Attending Skin-VD Outpatient Department in a Medical College Hospital of Bangladesh
}

\author{
Md. Rokon Uddin ${ }^{1}$, Khondaker Bulbul Sarwar ${ }^{2}$, Farjana Akhter ${ }^{3}$, Abu Baker ${ }^{4}$
}

\begin{abstract}
Background: The pattern of skin diseases varies from one country to another and even from region to region of the same country. We are geographically placed in the tropical region with natural outcome of communicable diseases. We conducted this cross sectional study in a tertiary hospital of Bangladesh keeping the proposition in mind that infectious diseases occupy maximum percentage among skin and venereal diseases in outpatients in Bangladesh. Objectives: To classify the diseases attending the Skin \& VD outpatient department of Enam Medical College Hospital (EMCH) and to draw comments and recommendations on the basis of findings. Materials and Methods: All patients irrespective of age and sex attending the OPD of Skin-VD Department of Enam Medical College Hospital during a 2-year time-period (from January 2009 to December 2010) were included in the study. Structured questionnaire, check-list and face-to-face interview (whenever necessary) were used as tools of data collection. Statistical analyses were done by SPSS version Windows 11.1. Results: Total number of patients was 12100. Most of the patients were aged (>18 years; $64.28 \%$ ), dominated by male $(61.63 \%)$, married $(56.1 \%)$, literate $(71.11 \%)$, coming from far $(>5 \mathrm{~km}$; $63.5 \%$ ) and of middle class origin (59.73\%). Out of the total cases, maximum (23.42\%) were diagnosed as eczema, followed by infectious diseases (17\%), acne (8.69\%) and psoriasis $(6.36 \%)$. Conclusion: In this study we found infectious diseases to occupy the second position next to eczema and our findings nullify the proposition that infectious diseases occupy maximum percentage among skin and venereal diseases in outpatients in Bangladesh.
\end{abstract}

Key words: Disease pattern, Infectious disease, Eczema, Socio-economic condition

J Enam Med Col 2011; 1(2): 67-70

\section{Introduction}

Bangladesh is a densely populated country having more than 150 million people in a 144 thousand square kilometer pocket. ${ }^{1}$ We are geographically placed in the tropical region with natural outcome of communicable diseases, notably burdened with noncommunicable and contagious diseases too. ${ }^{2}$ If we analyze the disease profile, we find that almost $19 \%$ of total OPD patients are suffering from skin diseases. ${ }^{3}$ The pattern of skin diseases varies from

one country to another and even from one region to another within the same country. ${ }^{4}$ Customs, habits, religious beliefs, languages, climate are not so varied in different parts in this country, but socio-economic conditions and ignorance play vital role for various presentations of dermatological condition. A number of workers have reported different patterns of skin diseases in different areas. ${ }^{5-10}$ We conducted this study in Skin \& VD outpatient department of Enam

\footnotetext{
1. Associate Professor, Department of Skin \& VD, Enam Medical College \& Hospital, Savar, Dhaka

2. Associate Professor, Department of Community Medicine, Ibn Sina Medical College, Dhaka.

3. Junior consultant, Skin \& VD, Upazilla Health Complex, Savar, Dhaka

4. Assistant Professor, Department of Skin \& VD, Enam Medical College \& Hospital, Savar, Dhaka
}

Correspondence Md. Rokon Uddin, Email: drrokon47@gmail.com; +8801711-392013. 
Medical College Hospital (EMCH), Savar, Dhaka and intended to draw recommendations based on the in-depth findings on prescribers, differential diagnoses, demographical conditions including literacy and the pattern how the clients came to the health facilities.

\section{Material and Methods}

This cross sectional study was carried out in the Skin \& VD outpatient department of Enam Medical College Hospital (EMCH), Savar, Dhaka for a full 2-year time period from January 2009 to December 2010. All patients attending outpatient department during this period were included in the study. Twelve thousand and one hundred patients attended Skin \& VD OPD during this period and were considered as study population. Patients able to read and write were considered as literate and unable to do it as illiterate. Distance less than $5 \mathrm{~km}$ from EMCH was considered as within Savar and above $5 \mathrm{~km}$ from as outside Savar. Data were collected by structured questionnaire, checklists and face to face interview (where necessary). Collected data were tabulated, analyzed and checked manually and finally computed by SPSS program (version 11.1).

\section{Results}

Table I shows age and sex distribution, marital status, literacy of the respondents and distance of their residence from Savar. Table II shows the referral types of the study subjects. Maximum number of subjects was sent by drug sellers or village doctors.

Table I: Basic demographic information of the respondents by selected variables $(\mathrm{N}=12100)$

\begin{tabular}{|l|c|c|}
\hline Demographic Variables & Number & Percentage \\
\hline $\begin{array}{l}\text { Age } \\
<18 \text { years }\end{array}$ & 4334 & \\
\hline 18 years & 7766 & 35.82 \\
Sex & & 64.18 \\
Male & 7458 & \\
Female & 4642 & 61.63 \\
Marital Status & & 38.37 \\
Married & 6788 & \\
Unmarried & 5312 & 56.1 \\
Literacy & & 43.9 \\
Illiterate & 3491 & \\
Literate & 8604 & 28.89 \\
Distance & & 71.11 \\
Within Savar & & \\
Outside Savar & 4417 & 36.5 \\
\end{tabular}

Table II: Distribution of patients by the category of reference

\begin{tabular}{lcc}
\hline Referral type & Frequency & Percentage \\
\hline Registered doctor & 1427 & 11.8 \\
Drug seller/village doctor & 5953 & 49.2 \\
Self & 4720 & 39.0 \\
\hline
\end{tabular}

The present study shows that 2048 (16.92\%) patients presented with infectious diseases, $2834(23.42 \%)$ cases were diagnosed as eczema, $770(6.36 \%)$ had psoriasis, 1052 $(8.69 \%)$ had acne, $286(6.84 \%)$ were of anxiety neurosis, $988(8.16 \%)$ were of erectile dysfunction and rest 3580 (29.58\%) were of mixed or other dermatological symptoms (Fig 1).

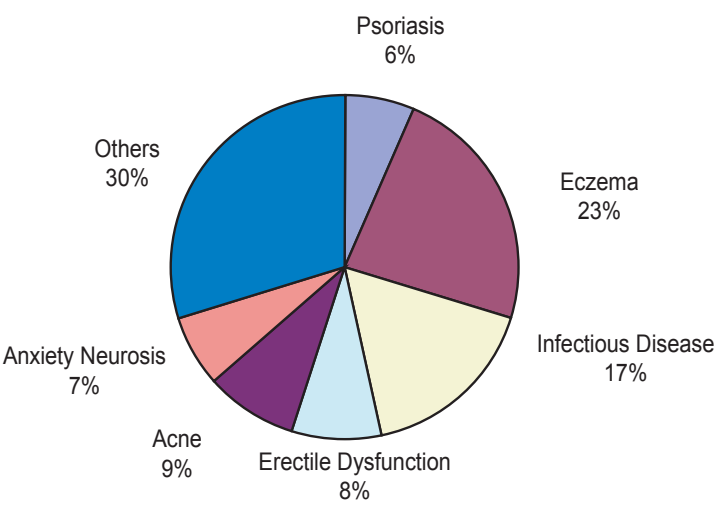

Fig 1. Pattern of diseases attending Skin \& VD OPD

Fig 2 shows different types of infectious diseases. Four hundred fifty two $(22.07 \%)$ respondents were diagnosed as scabies, 876 $(42.77 \%)$ respondents had fungal infection, $240(11.17 \%)$ had STIs, 298 had (14.55\%) viral diseases and only 16 were Hansen's disease (leprosy) patients.

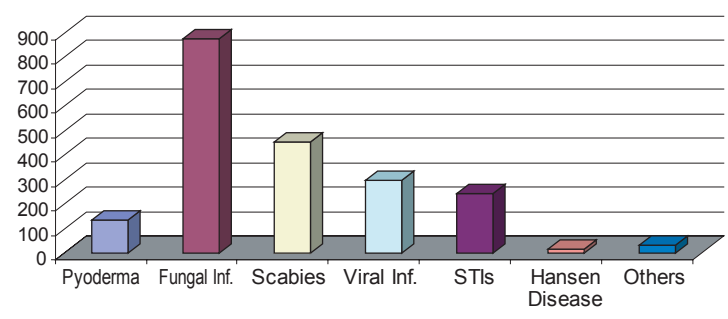

Fig 2. Types of infectious diseases in respondents $(\mathrm{N}=2048)$ 
Fig 3 shows the different types of eczematous diseases. Maximum numbers $(908,32.04 \%$ ) of respondents were diagnosed as seborrheic dermatitis followed by atopic dermatitis $(820,28.93 \%)$ and contact dermatitis $(542,19.12 \%)$.

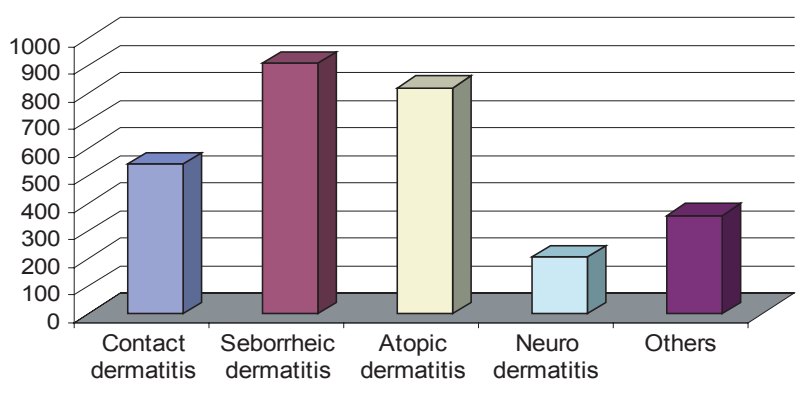

Fig 3. Types of eczematous diseases attending Skin \& VD OPD $(\mathrm{N}=2834)$

Table III shows the different types of fungal diseases. Five hundred ninety two $(67.58 \%)$ respondents were diagnosed having dermatophytic infection, 185 as pityriasis versicolor, 92 as candidiasis and 7 cases were caused by deep fungus.

Table III: Pattern of fungal diseases attending Skin \& VD OPD $(\mathrm{N}=876)$

\begin{tabular}{lcc}
\hline Disease pattern & Number & Percentage \\
\hline Dermatophytes & 592 & 67.58 \\
Pityriasis versicolor & 185 & 21.12 \\
Candidiasis & 92 & 10.50 \\
Deep fungus & 7 & 0.80 \\
\hline
\end{tabular}

Table IV shows the distribution of viral diseases. Herpes simplex occupies maximum number of cases (72; 29\%) among viral diseases followed by chicken pox $64(26 \%)$, herpes zoster $54(22 \%)$ and verruca $30(12 \%)$.

Table IV: Distribution of viral diseases $(\mathrm{N}=298)$

\begin{tabular}{lcc}
\hline Disease & Frequency & Percentage \\
\hline Herpes Zoster & 54 & 22 \\
Herpes Simplex & 72 & 29 \\
Chicken pox & 64 & 26 \\
Verruca & 30 & 12 \\
Others & 28 & 11 \\
Total & 298 & 100 \\
\hline
\end{tabular}

Table V shows that gonorrhea $132(55 \%)$ occupies maximum portion of the STIs, followed by nongonococcal urethritis $58(24 \%)$, chancroid 18 $(8 \%)$ and chancre $12(5 \%)$.

Table V: Pattern of STI patients by specific subclassification $(\mathrm{N}=240)$

\begin{tabular}{lcc}
\hline Disease & Frequency & Percentage \\
\hline Gonorrhoea & 132 & 55 \\
Chancre & 12 & 5 \\
Chancroid & 18 & 8 \\
NGU & 58 & 24 \\
Others & 20 & 8 \\
Total & 240 & 100 \\
\hline
\end{tabular}

\section{Discussion}

This two-year long cross sectional study revealed that out of the total 12100 cases attending Skin \& VD outpatient department, maximum cases $(23.42 \%)$ were diagnosed as eczema. Similar findings were also reported by other researchers in different regions in India. $5,7,8,11-13$

This study also revealed that infectious diseases formed the second largest group (16.92\%) of skin diseases. Out of 2048 infectious disease patients 452 were diagnosed as scabies which was only $3.7 \%$ of total OPD patients in Skin \& VD department. Low attendance of scabies patients may be due to following socio-demographic factors.

1. OPD ticket cost is very high for low socioeconomic condition group.

2. Scabies with other infectious diseases are more prevalent among this group.

3. A government OPD centre (UHC) is located within half $\mathrm{km}$ from the Skin \& VD OPD of EMCH.

This study also reveals fungal infection as the highest group of infectious diseases. The warm and humid climate of the country may account for this high incidence of fungal diseases. In this study we also found that the incidence of viral infection was relatively low $(2.46 \%)$ as compared to similar studies done in Kashmir $(14 \%)^{12}$, in Trivandrum $(5.10 \%)^{13}$ and in Pune $(7.1 \%)^{14}$. This difference was due to inaccessibility of all groups of patients in private 
medical outdoor. We also found that herpes simplex was the commonest viral infection (29\%).

The low incidence $(0.13 \%)$ of Hansen's disease in this study is due to the fact that such patients mainly attend leprosy centres where the medicines (MDT) are given free of cost and these facilities are available throughout the country. Low incidence of STIs (1.98\%) may be because such patients preferred to maintain privacy and attend private clinics to avoid the harassment of social oppression and stigma associated with the disease.

Based on the findings and analyses of the results of similar studies at home and abroad we like to make following recommendations to draw attention of the policy makers, specialists in Skin \& VD and future researchers.

1. No case should be diagnosed blindly and categorized under gross classification, unless there is adequate proof. The blind forecasting might lead to wrong directions.

2. Not any proposition, even done by the specialists, should be taken as readymadedecision. Researcher should come forward to justify their hypothesis through scientific study and statistical findings.

3. Though a major portion of the total patients attending Skin-VD OPD is diagnosed as dermatological cases, but it cannot be confirmed blindly. Confirmation of the diagnosis of Skin-VD cases should be done very cautiously and meticulously.

\section{References}

1. Bangladesh Bureau of Statistics (BBS) Pocketbook, 2008.

2. Morshed M, Anowar I, Sarwar KB et al. Epidemiological surveillance report 1999: 269-281. Yearly health situation report 2000, IEDCR, Mohakhali, Dhaka.
3. Bonifaz A et al. Treatment for fungal infections of the skin of the foot. Cochrane database system rev 2002; 2: CD003584.

4. Rook A, Savin JA, Wilkinson DS. The prevalence, incidence and ecology of diseases of skin. In: Rook A, Wilknson DS, Ebling FJG, Champion RH, Burton JL (eds). Textbook of dermatology. 7th edn. Bombay: Oxford University Press, 1987: 39-53.

5. Mehta TK. Pattern of skin diseases in India. Ind J Dermatol Venereol 1962; 28: 134-139.

6. Gupta RN, Jain VC, Chandra R. Study of sociomorbid pattern at the skin outpatient department of a teaching hospital in summer and winter season. Ind J Dermatol Venereol 1968; 34: 241-244.

7. Gangagharan C, Joseph A, Sarojini A. Pattern of skin diseases in Kerala. Ind J Dermatol Venereol 1976; 42: 49.

8. Dayal SG, Gupta GP. A cross section of skin diseases in Bundelkhand region, UP. Ind J Dermatol Venereol 1977; 43: 258-261.

9. Behl PN, Mohanty KC, Banergee S. Ecological study of skin diseases in Delhi area. Ind J Dermatol Venereol 1979; 45: 260-264.

10. Mahalingam C. Prevalence of dermatoses in tribal population of Kalrayan hills (South Arcot district). Ind J Dermatol Venereol 1986; 52: 213-215.

11. Jaiswal AK, Gurmail S. Pattern of skin diseases in Kashmir region of India. Indian J Dermatol Venereol Leprol 1999; 65: 258-260.

12. Nair SP, Nair TV, Krishnan G. Pattern of dermatological diseases in Trivandrum. Indian J Dermatol Venereol Leprol 1999; 65: 261-263.

13. Kuruvilla M, Sridhar KS, Kumar P, Rao SG. Pattern of skin diseases in Bantwal Taluq, Dakshina Kannada. Indian J Dermatol Venereol Leprol 2000; 66: 247-248.

14. Sayal SK, Das AL, Gupta CM. Pattern of skin diseases among civil population and armed forces personnel at Pune. Indian J Dermatol Venereol Leprol 1997; 6: 29-32. 